\title{
Wanted - An Italian Husband
}

\author{
Introduction and translation from Italian by Nataliya Sharlay \\ University of Alberta, Canada
}

Voglio un Marito Italiano is a novel published by Edizioni Il Punto d'Incontro in 2006. It was written by Marina Sorina who is originally from Ukraine but now lives and works in Italy. Through the life story of her heroine, Svetlana, a young girl who represents a unique phenomenon of female immigration, she paints a picture of a collective character, a Slavic woman who seeks a new and better life in the Western world, namely in Italy. Svetlana is an image for hundreds of thousands of women who have migrated in the past 20 years from the Eastern Europe to the West.

The translation is a collage of the key passages, which should give a reader a general idea of the content. They also present the main social and cultural points that are discussed by the author in the novel. This publication was possible thanks to the publisher's kind permission.

\section{p.14}

I could not do it anymore. I was tired, tired to death of sitting on that shaky stool all the time. I was young, good looking, and smart. Why should I spend my very best years locked in a cell of iron and plastic, being "baked" in the summer time, and "frozen" in the winter, trying to stay alive with the help of a little, old fashioned stove? Season after season, month after month, year after year...

\section{p.16}

The days were all the same: I got up early, folded the sheets and hid them under my pillow. I hastily drank a cup of hot tea, and hurried into the darkness to catch a bus full of people who were still sleepy. (...)

In the evening I repeated my every step, but in reverse order: I collected the stuff, closed the place, and crossed the market that seemed now deserted. On my way home I sat on the bus full of people who already slept.

\section{p. 17}

That was my life at the age of twenty. And yet there was something that distinguished me from the crowd. Like everybody else I was clutching the walls of the bus that was jumping crazily struggling to keep up with the wild curves of the bumpy road, and trying to hold my balance with the help of the bags. Like everybody else I closed my eyes, trying to get rid of the annoying images of the day. But behind my closed eyelids the present was quickly fading and colourful images were emerging. I had a secret dream. And this dream protected me, helped me to jump over the puddles of mud and melted snow without slipping. My dream was Italy. How did it start? With a little detail, with that insignificant occasion that sometimes changes one's whole life. For my sixth birthday auntie Natasha brought me a very special gift. (...) 
The dress that she gave me on that day was of a simple cut, made of fabric that was very soft and decorated in a way I had never seen before. The light blue background was painted with colourful flowers and little branches. It was all covered with elegant writings in some strange language with intricate drawings which formed the images of unreal fairy tale places. Tickling my imagination, frowning rocky peeks surrounded an azure sea, cities were joyfully running down to the shores in dazzling white flowery clusters, and a clear line of ancient columns proudly stood out against the bright sky. Enchanted, I couldn't take my eyes off the dress. Accustomed to gray and square houses, I could not believe that these images were anything more than just a beautiful fantasy.

\section{p. 18}

From then on I knew exactly what I wanted to do when I grew up-I wanted to be an Italian! This answer of mine to the question about my future plans inevitably made adults laugh. Very few of them suspected how really serious I was in those moments. From that day on, the images of the sunny and carefree place were carved into my mind. I stubbornly wore that dress even when my legs became way too long for it. Then I tried to prolong its life by pretending that it was a mini that had just come into fashion. When finally I had to surrender to the fact that my favourite dress was gradually becoming a rug, I folded it carefully and hid it in the depths of my wardrobe. That is how my dream started. In the years that followed I surrounded this first nucleus with many other pieces of information, bit by bit creating my own fairy tale. In everything and everywhere I sought confirmation of Italy's existence-in books, movies and paintings ... When I was seven years old I worshipped Gianni Rodari. I first got to know him by listening to the tunes hummed by mom Ljuda. Later, I ventured on my own into the "Adventures of Cipollino", "Fairy tales on the phone" and "Gelsomino in the country of liars ".Then I discovered historical romances and fell in love with the adventures of the wandering knights. In high school the world literature classes helped me a lot; we studied Dante and Boccaccio and read descriptions of vagabonds or romantic heroes who invariably ended up arriving on the Italian shores. We knew all of the glorious past of ancient Rome, the darkness of the Middle Ages, and the luminous light of Renaissance and Humanism.

\section{p. 21}

It wasn't just me but most of the people I knew, imagined Italians as good-natured, happy, open and communicative people; always cheerful, sincere, generous, and by virtue of these qualities, they appeared to be close to what Russians and Ukrainians thought of themselves. In the villages of the part of Ukraine where I lived, there still were old people who remembered the presence of Italians during World War II. "The Italians were very kind soldiers," they said, "they gave chocolates to children and didn't kill anyone. They really seemed to be a different race compared to Germans. Those were like beasts, while Italians ... they were a little bit like us." Another common element, expressed in neo-realistic films, was the ethics of the poor people who stood together trying to survive in this world. In a world of poverty family was very important and friendship-sacred. At 
the bottom of my heart, I associated myself with those poorest of the poor who only needed a bottle of a good wine and the company of a beautiful woman, to be able to magically transform their miserable lives into magnificent ones. The men I saw in Italian movies were very manly, but at the same time they were very sensitive and expressive in showing their feelings. They were never confused or clumsy, because poverty didn't crush their spirits, and they wore their shabby jackets with extreme elegance.

\section{p. 137}

In the first months after I moved to Verona, I lived in full ignorance of the fact that the difference between me and the family that employed me, was not so much on an economical, but more on a social level. They were cold and distant with me not for a simple reason of being better off, but rather because they truly believed that they belong to a different race, and thus, they acted accordingly. This was the fact that drove me crazy. I couldn't agree to the idea that my place of origins was good enough reason for seeing me as someone inferior to themselves. They did not need to focus on my proletarian roots, it was enough for me to be a "Slavic" girl, to be treated like a beast.

p. 140

All the credit that I gave Italians before I ever stepped on Italian soil, and all the admiration I had for their ways of life, now were gradually disappearing. People like those I knew - whiny, irritable and short-tempered, self-righteous, selfish and superficial evoked in me nothing else but a profound despise.

p. 284

In the first few years, the formality and coldness of relations between people amazed me. Where were neighbours shouting from window to window, doors wide open to everyone in the neighborhood, openness and lightness of everyday communication? Over time I got used to the closure of Italian life. Every morning I got on the bus, stamped the ticket, and then got off a few stops later. I wasn't shocked anymore that neither in the morning nor at night, for many years in a row, no one ever thought of greeting me or starting a little friendly chat. I always saw the same girls, I could guess their mood by the expression on their faces, I knew their clothes, but not their names; each one with her own ticket and thoughts, separated by the distance of two millimeters at most.

p. 280

A lifetime wouldn't be enough to understand those rules completely. After my first five years in Italy my working hypothesis was the following: Italian society was so afraid to disturb the fellow neighbour that in an attempt to ensure his peace, it ignored him altogether. Another thing that I noticed was a peculiar hierarchy in greeting customs, where parents came first and wives last. The required balance was achieved in various ways. For example, when we returned from a vacation and Gianmarco drove us from the airport, Franco always sat next to him, "If not," he said, "Dad would 
feel as a taxi driver." "Really? Why should he feel that way?"-I was wondering- "wouldn't it be a joy for his heart to see his children in love, sitting together locked in a passionate embrace?"

Another point was the family gatherings. To be perfectly appropriate we refrained from going to see relatives too often. Same with Lorella's sisters, who would come to see her only on strictly appointed days and on her birthday. First, I thought that they didn't get along very well; but over the years I realized that they had the best intentions and exactly for that reason they would never even think of coming over without notice. It would be very embarrassing to find her in her pyjamas and the house looking less than perfect. It was vitally important to show off the best of yourself and give others a chance to do the same. It did not matter that the house was always sparkling clean and Lorella's nightgowns were made of the best quality silk and suited her very nicely. It wasn't appropriate. Just that.

If I asked about the reasons for these peculiar rules, they told me those were the rules of courtesy, as courtesy has such a unique value that overrides everything else. I personally found it very rude and void of any courtesy that nobody gives a hand to an old woman getting off the bus, no one offers a seat to a pregnant woman, and no one helps a lady with her coat when leaving an elegant restaurant. Oh no, they said, to do so means to violate the sense of one's privacy and independence, we are not doing it anymore! Noticing the confused expression on my face, they would start talking about feminism and "so it was here thirty years ago"... I couldn't see why feminism was so important in a country where almost everyone went to Mass on Sundays. Wasn't it just a pretext for not thinking about others, for ignoring them?

Even more difficult for me was to understand social relations. And language had nothing to do with this. I had been studying Italian for ten years and the practice that I have got when I started working in Italy made me almost proficient in it. I had such a good command of the language that I heard the same remark almost all the time: "Wow! You speak perfect Italian!" said with the amazement of someone who hears a parrot talking. Often it was followed by: "You, Slavs, are all gifted for languages." It didn't matter that I had spent years studying Italian to fit that category of "us, Slavs". All of "us" were different and had no special talent for languages, but rather a life necessity to learn them.

p. 294

In the years preceding my marriage I strived to become a real Italian, just like the others. I tried to adopt the ways of doing and saying that were the most appropriate for my Italian counterparts. I cultivated the same interests and explored il mare magnum of the Italian past and present, making the country that always fascinated me my home.

p. 289

After five years spent in Bel Paese I had very few illusions about the success of my integration into Italian society. I was still a foreigner and would remain so until the end of my days. There was nothing that I could do about it. 